\title{
CRITERIA FOR ASSESSING THE QUALITY OF ENERGY SOLID FUELS IN THE CONTEXT ASSESSMENT OF CO2 EMISSIONS
}

Mona Barbu; Elena Bucur; Mihaela Petrescu; Mihai Bratu

National Research and Development Institute for Industrial Ecology - INCD ECOIND, 71-73 Drumul Podu Dambovitei Street, 060652, Bucharest, Romania-

\section{Abstract}

In an economy increasingly globalized a country's energy strategy is done in the context of changes and developments taking place worldwide. Due to increasing energy demand, energy has developed rapidly without the problem of environmental protection.

Total energy demand in 2030 will be about $50 \%$ higher than in 2003, and oil will be about $46 \%$ higher. Known oil proven reserves can sustain current levels of consumption only until 2040, and the gas until 2070, while world reserves of coal provides for more than 200 years to an increase in the level of operation.

It is estimated that about a quarter of primary energy resources globally, will be covered further in coal. Along with increasing energy consumption will increase consumption of coal.

This paper presents criteria for assessing the physico-chemical characteristics of solid fuels in the context of $\mathrm{CO} 2$ emissions. From the experimental laboratory research were highlighted as key parts for coal composition are organic mass; inorganic mass and water. Knowing ash content and the amount of moisture we can estimate the energy value of a fuel conjunction with carbon content present in the coal fuel.

Keywords: solid fuels, coal fuel, carbon dioxide emissions

\section{Introduction}

Energy has become a strategic factor in global politics, a vital component and a cost factor for economic development and progress of society as a whole, generating a series of major global concern. At EU level, it was found that the greatest amount of $\mathrm{CO} 2$ emissions resulting from energy and transport..

Energy generation is based on a variety of fuels that can be classified in general, depending on their aggregate state into solid, liquid or gaseous. [1], [2], [3] It is estimated that about one quarter of primary energy resources, globally, will still be covered in coal. While increasing energy consumption and consumption of coal will increase. [3]

The paper aims to provide criteria for assessing the physico-chemical characteristics of solid fuels in energy sector USE THE Romania, in the context

CO2 emissions assessment. [4]. In general, a solid fuel consists of mass organic, inorganic and water table. 
Organic mass $(\mathrm{C}, \mathrm{H}, \mathrm{N}, \mathrm{S}, \mathrm{O})$ is the most important coal because it is the one that determines the properties and characteristics that make basic raw material coal to coking and good capitalization fuel for different energy. The composition and properties of organic mass chemical or geological age varies with the species of coal, the conditions of deposit, etc. [4].



Figure 1. The average composition of the fuel mass

Inorganic mass minerals is comprised of genetic material contained in the ignition is turned to ash. [4], [5].

Water is a major disadvantage present in the fuel, as it requires an amount of heat for evaporation and reduces its calorific value. The water table is partially linked to organic and inorganic partial mass (inorganic) [4]

Water/moisture and mass inorganic (mineral) that is combustible ballast worse quality coal energy. [4].

Humidity is composed of:

- moisture (free) or superficial (surface) of wide capillaries which has vapor pressure is normal and quite easily removed by simply storing in air;

- $\quad$ hygroscopic humidity represents physically bound water from the internal pore structure has lower vapor pressure is normal pressure and temperature waived only by drying over $100 \mathrm{oC}$ (105oC respectively). [6]

Currently humidity is defined as the total amount of the hygroscopic humidity and moisture.

Organic fuels various combinations of the elements $\mathrm{C}, \mathrm{H}, \mathrm{S}$ (fuel elements), $\mathrm{O}$ and $\mathrm{N}$, with moisture (Wt) and minerals that transform in ash. [7]

Fuel composition can be determined by technical analysis and elemental chemical analysis. [8], [9]. By elemental analysis to determine the percentage content of $\mathrm{C}, \mathrm{H}, \mathrm{N}, \mathrm{O}, \mathrm{S}$ mass of organic fuel, and through technical analysis to determine humidity, materials volatile, ash and coal fix. Oxireactivity is the property of classic fuel / alternative react with oxygen. Oxireactivity generally is higher when fuels are younger.

The calorific value of a fuel is the amount of heat generated in the complete combustion of a quantity of the sample in oxygen atmosphere. It is 
expressed in different units gives the measure: cal / g, Kcal / kg, J / g, kJ / kg, $\mathrm{MJ} / \mathrm{kg}$. Any fuel has a power calorific upper and lower. [10]

Calorific value assumes that the water vapor was condensed and returned the heat of evaporation. Lower heating value is determined by calculation, deducting the heat from the power calorific superior water vapor condensation of combustion gases. [10], [11]

\section{Experimental methods}

The experimental laboratory research has revealed that by determining the ash content and the amount of moisture can appreciate the value of fuel energy in conjunction with currently-fuel carbon content.

Between the years 2008-2015 was carried out in the INCD ECOIND monitoring $\mathrm{CO} 2$ emission factor [12] for different types of samples of coal: coal, lignite, brown coal mixed with biomass, used currently in various units of energy in Romania. (CET PAROSENI, CET IASI; CET ORADEA, CET ARAD, CET GOVORA, CET ISALNITA, CET CRAIOVA, COLTERM TIMISOARA, CET BACAU, ROMAG DROBETA - Turnu Severin, CET BRASOV, etc).

The experiments led to the development work addresses the following issues:

- the influence of moisture and ash from coal on the calorific value of the respective energy;

- interdependence between carbon content and CO2 emission factor;

- biomass influence mixed with solid fuel (lignite) and default emission factor that reducing $\mathrm{CO} 2$ emissions

Samples representative samples in the paper were:

- Lignite - L

- Biomass- B

- Huila - H

- Lignite+Biomass- $\mathrm{L}+\mathrm{B}$

Samples were subjected to solid fuels specific analysis: moisture (Wi); hygroscopic moisture (Wh); The total moisture content (Wt), ash (A), elemental analysis (carbon $\mathrm{C}$, hydrogen $\mathrm{H}$, the $\mathrm{S}-\mathrm{S}$, nitrogen $\mathrm{N}$, oxygen $\mathrm{O}$ ) and determination of the gross calorific value (Qs) and lower (Qi).

For determining elemental analysis $(\mathrm{CH}, \mathrm{S}, \mathrm{N})$ using a Thermo Elemental Analyzer EA Fisher Scientific Fleash 1112 and calorific value was determined using a bomb calorimeter Parr 6200. The analyses presented were conducted in accordance with national standards in force and international [6-10].

Analytical results for the samples tested were recalculated fuel to its original state (assigning index i) in accordance with standard STAS 398/82 [11]

\section{Results and Discussion}

Laboratory experiments shows the influence of moisture and ash content of the fuel quality and the role addition of biomass where quality coal (lignite). [13] The analytical results are shown in Table 1. 
Table 1 -Laboratory test results

\begin{tabular}{|c|c|c|c|c|c|c|c|c|c|c|c|c|c|c|}
\hline \multirow[b]{2}{*}{ 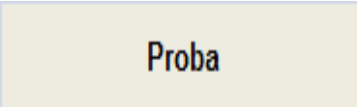 } & $W_{i}^{i}$ & $w_{h}{ }^{i} \mid$ & $W_{t}^{i}$ & $A^{i}$ & $S_{t}^{i}$ & $C^{i}$ & $H^{i}$ & $N^{i}$ & $0^{i}$ & $0_{s}{ }^{i}$ & $0_{s}^{i}$ & $Q_{i}^{i}$ & $Q_{i}^{i}$ & $\mathrm{Fe}$ \\
\hline & $\%$ & $\%$ & $\%$ & $\%$ & $\%$ & $\%$ & $\%$ & $\%$ & $\%$ & $\mathrm{kcal} / \mathrm{kg}$ & $\mathrm{kJ} / \mathrm{kg}$ & $\mathrm{kcal} / \mathrm{kg}$ & $\mathrm{kJ} / \mathrm{kg}$ & $\mathrm{CO} / \mathrm{TJ}$ \\
\hline & 4.76 & 7.46 & 42.22 & 21.79 & 1.68 & 22.08 & 2.67 & 0.74 & 8.82 & 2157 & 9033 & 1770 & 7412 & 109.22 \\
\hline B & 39.04 & 3.99 & 43.03 & 0.57 & 0.01 & 29.91 & 3.90 & 0.09 & 22.48 & \begin{tabular}{|l|} 
\\
\end{tabular} 921 & 12228 & 2464 & 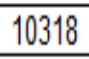 & 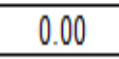 \\
\hline Huila. & 5.83 & 2.24 & 8.07 & 15.21 & 1.48 & 61.82 & 3.42 & 2.05 & 7.95 & 5994 & 25095 & 5768 & 24148 & 93.87 \\
\hline ignite $+17 \% \mathrm{Bi}$ & 37.78 & 7.72 & 45.50 & 17.20 & 1.23 & 24.57 & 2.81 & 1.17 & 7.52 & 2235 & 9357 & 1821 & 7624 & 90.00 \\
\hline
\end{tabular}

In laboratory experiments conducted for the 4 samples is seen as a test of lignite shows ash content and humidity higher than coal sample. (Figure 2) This is because, coal is lignite coal. Sample quality is enhanced by the addition of lignite, biomass present in a proportion of about $17 \%$ in the blend. Influence of biomass has many advantages both for improving the inferior quality of fuel (lignite) by reducing ash content and thus the ballast combustible, low sulfur content and in terms of increasing calorific power and not least, the reduction factor for emissions $\mathrm{CO} 2$. It also observes a strong connection between carbon content and calorific value. Through a trick of calculation, knowing content of carbon fuel sample can be approximated topcoated its calorific value.

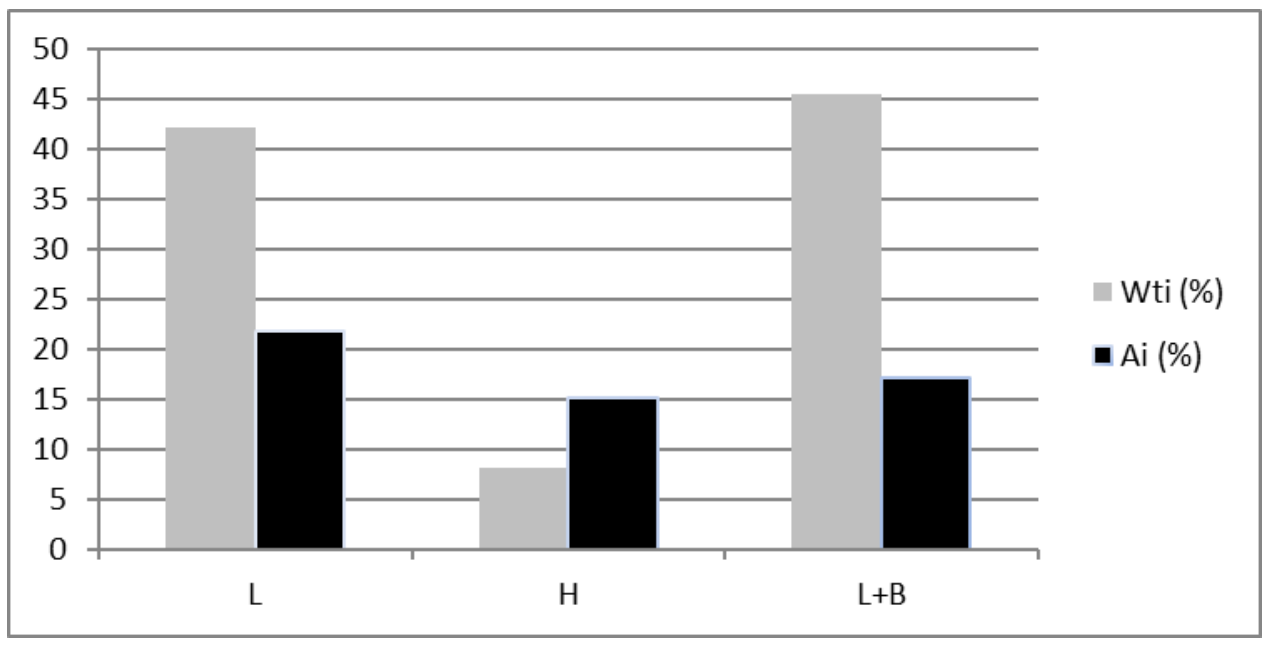

Sample

Figure 2 - Variation in total moisture content and ash samples lignite coal lignite and biomass

In Figure 3 shows the effect of ash content on the fuel quality in terms of energy, ie the higher moisture and ash content is higher the calorific power is less or vice versa. 




Figure 3 - Influence of content of ash on calorific power in the samples of lignite, biomass, coal and lignite with biomass

Figure 4 shows the variation in emission factor depending on the carbon content samples of lignite, biomass, coal and biomass.

The mixture of biomass in the sample of lignite lead to reduce $\mathrm{CO} 2$ emission factor for lignite sample, close in value to the coal obtained from the sample.

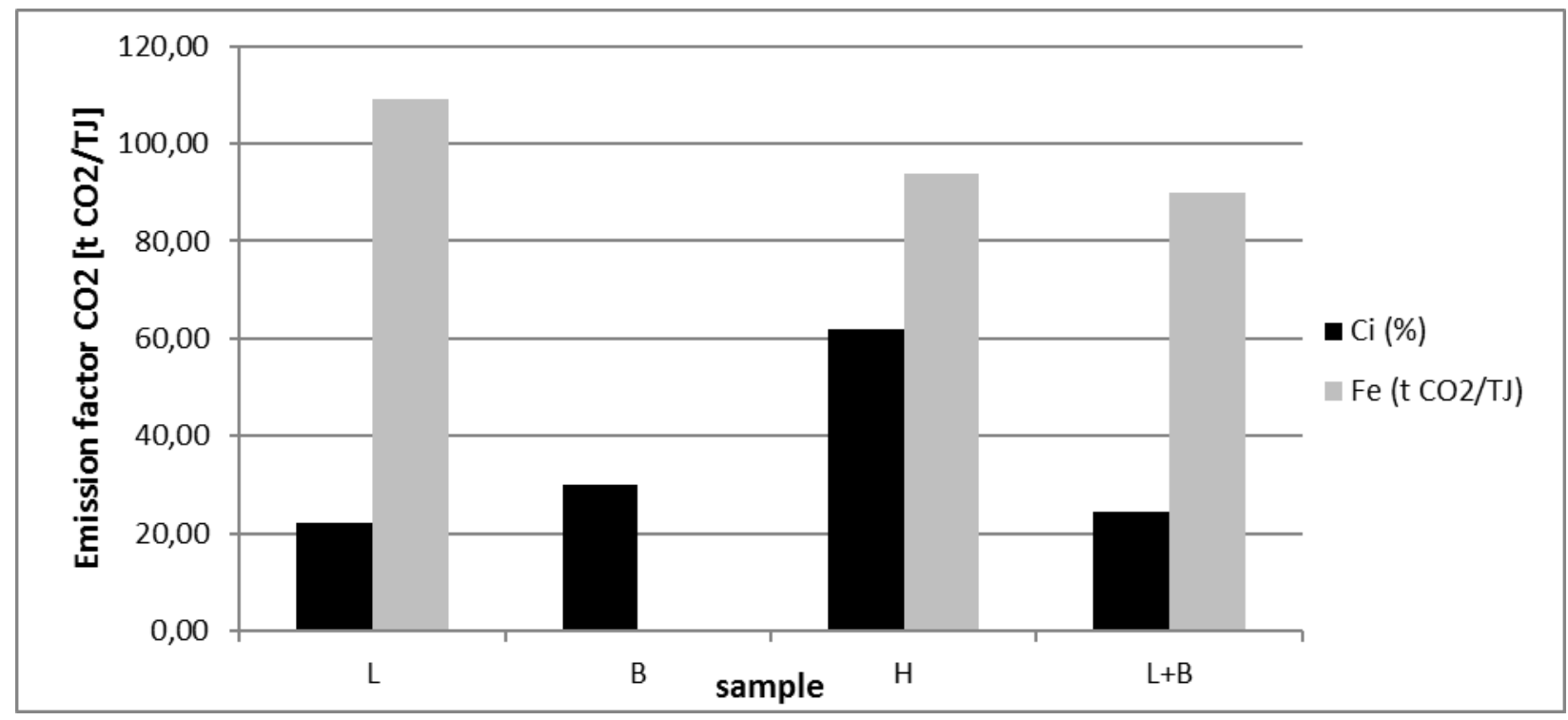

Figure 4 - Factor variation depending on the content of carbon emission samples of lignite, biomass, huila and lignite mixture of biomass 


\section{Conclusions}

The paper outlines the criteria for assessment of physicochemical characteristics of solid fuels in the context of $\mathrm{CO} 2$ emissions. The experimental laboratory research showed that the main were constituent parts of the composition coals are organic meals; inorganic mass and water. Knowing the ash content and the amount of moisture can appreciate the value of a fuel energy in conjunction with the carbon content of coal.

It shows a strong connection between carbon content and calorific value. Through a trick of calculation, knowing the carbon content of fuel sample can be approximated topcoated its calorific value.

The addition of solid biomass in lower fuel (lignite) gave the following results: carbon content increases by approx. $3 \%$ to evidence of lignite $(\mathrm{L})$; sh percentage decreases by about $4 \%$; increase the calorific value of approx. $200 \mathrm{~kJ} / \mathrm{kg}$;

By using lower coal mixed with biomass reduces the amount of solid fuels, improve energy properties of inferior fuels (lignite) and decreases the amount of CO2 emission with $19 \%$, achieving a value close to that of higher coal- Huila

\section{Acknowledgements}

The tests have been done inside the INCD ECOIND Bucharest and we thank with this opportunity for all the support.

\section{References}

[1] V. Sebastian-Călin , PhD thesis, Economic and Financial Feasibility of Renewable Energy Resources, University of Agricultural Sciences and Veterinary Medicine Cluj Napoca, 2012.

[2] Romania's energy strategy for 2007-2020, www.minind.ro/energie/STRATEGIA_energetică_actualizată.

[3] S.Ladanai, J.Winterbäch, Report: Global potential of sustainable biomass for energy, Swedish University of Agricultural Sciences, Department of Energy and Technology, 2009.

[4] Handbook chemical engineer, technical publisher vol II

[5] M.Jaccard, Sustainable Fossil Fuels, Cambridge University Press, 2005.

[6] SR 5264:1995 - Solid mineral fuels. Coal. Determining moisture.

[7] ISO 1171:2010 - Solid mineral fuels. Determination of ash.

[8] ASTM D 5373:2014 - Standard methods of analysis for determining instrumental carbon, hydrogen and nitrogen in the sample of solid fuels.

[9] ISO 351:1996 - Solid mineral fuels. Dosage total sulfur. Method of combustion at high temperature

[10] ISO 1928:2009 - Solid mineral fuels. Determination of gross calorific value by the bomb calorimeter and calculation inferior calorific value

[11] STAS 398/92 - Fuels solid. Symbols for specific analytic and factors for recalculation of analysis results.

[12] Commission regulation (EU) NO. 601/2012 on monitoring and reporting of greenhouse gas emissions in accordance with the effect Directive 2003/87/EC of the European Parliament and the Council.

[13] M. Barbu, M.Bratu, O. Dumitrescu, The influence of biomass use on CO2, emissions resulted from burning solid fuels in the energy sector, Romanian Journal of Materials, 2015, 45 (2) 